\title{
Nonconventional concrete hollow blocks evaluation by destructive and non-destructive testing
}

\section{Avaliação de blocos de concreto vazados não convencionais por ensaios não destrutivos e destrutivos}

M.S. RODRIGUES a michatcsr@yahoo.com.br

G.C.S. FERREIRA b gisleiva@ft.unicamp.br

L. SHIROMA c leandro@recicon.com.br

A.L. BERALDO d beraldo@feagri.unicamp.br

\begin{abstract}
The aim of this study was to evaluate cementitious matrices properties by partial replacement of Portland cement by silica fume (SF) or by rice husk ash (RHA), and their application in nonbearing hollow blocks, tested by destructive and non-destructive methods. The following mixtures were produced: reference ( $100 \%$ of Portland cement) and Portland cement replacement (10\% by mass) with SF or RHA. The non-destructive testing showed that the highest values of UPV were obtained for SF-based blocks and RHA-based blocks. The destructive test showed better results for SF-based blocks, but there was no statistical difference between the RHA-based and control ones.
\end{abstract}

Keywords: concrete hollow blocks, rice husk ash, pozzolan, non-destructive testing.

\section{Resumo}

O objetivo desse estudo foi o de avaliar as propriedades de matrizes cimentícias com a substituição parcial do cimento Portland por sílica ativa (SA) ou cinza de casca de arroz (CCA) e suas aplicações em blocos de concreto não estruturais, avaliados por métodos destrutivos e não destrutivos. As seguintes misturas foram produzidas: referencia (100\% de cimento Portland), e mistura de cimento com SA ou CCA (10\% de substituição, em massa). O ensaio não destrutivo mostrou que maiores valores de velocidade do pulso ultra-sônico (VPU) foram dos blocos com SA e com CCA. No ensaio destrutivo, os melhores resultados foram obtidos para os blocos com SA, mas não há diferença estatisticamente significativa entre os blocos com CCA e os blocos controle.

Palavras-chave: blocos de concreto vazados, cinza de casca de arroz, pozolana, ensaio não destrutivo

\footnotetext{
Agricultural Engineering, State University of Campinas, michatcsr@yahoo.com.br. Av. Candido Rondon, 501, Cidade Universitária Zeferino Vaz, zip code 13083-875, Barão Geraldo, Campinas, São Paulo, Brazil

- Faculty of Technology, State University of Campinas, gisleiva@ft.unicamp.br. Rua Paschoal Marmo, 1888, zip code 13484-332, Limeira, São Paulo, Brazil

Agricultural Engineering, State University of Campinas, leandro@recicon.com.br. Av. Candido Rondon, 501, Cidade Universitária Zeferino Vaz, zip code 13083-875, Barão Geraldo, Campinas, São Paulo, Brazil

d Agricultural Engineering, State University of Campinas, beraldo@feagri.unicamp.br. Av. Candido Rondon, 501, Cidade Universitária Zeferino Vaz, zip code 13083-875, Barão Geraldo, Campinas, São Paulo, Brazil
} 


\section{Introduction}

Concrete hollow blocks applications are common in many countries. However, the manufacture of these blocks does not provide satisfactory technology control due to the need for quick release of the lots. Brazilian and international standards (ABNT NBR6136 [1], ASTM C55-11 [2], BS 6073/81 [3]) describe hollow blocks compressive test at 28 days old, but this period can be considered long for practical purposes. Therefore, the need for more rapid testing enables the application of non-destructive testing (ultrasound) for materials characterization.

Prassianakis \& Prassianakis [4] evaluated the ability of non-destructive testing to determine the integrity of concrete specimens, and they concluded that this methodology is feasible for blocks evaluation.

Hamid et al. [5] performed ultrasound tests on high performance concrete (HPC), with the addition of silica fume, on cubic specimens of $150 \mathrm{~mm}$ side. After that, the specimens were tested in compression. Results confirmed that ultrasonic pulse velocity (UPV) change was more evident between 1 and 14 days and that UPV increases only slightly at older ages (28, 56 and 90 days old). Moreover, there is an actual need to adopt practices to minimize environmental impacts with the use of admixtures in Portland cement (SNIC [6]). The use of ash from agro-industrial and pozzolanic materials allow reducing the Portland cement consumption, thus making cement industry more sustainable. Additionally, cement replacement by ashes also improves the mechanical characteristics and the durability of cementitious matrices.

According to Mehta and Monteiro [7], the highly reactive pozzolan, even when present in small contents $(30 \%)$ in a cementitious matrix, is able to consume almost completely calcium hydroxide, thus improving not only the mechanical strength but also the resistance to acid and sulfate attacks.

Researchers studied the use of silica fume in concrete, comparing the results of destructive and non-destructive testing (ultrasound). They observed that the mixtures with higher percentage of silica fume $(30 \%)$ had smaller UPV when compared with mixtures with $10 \%$ and $20 \%$ silica fume. This can be justified because, with silica fume utilization, concrete becomes less dense, despite showing the same compressive strength (Hamid [5]).

Cement-based materials are heterogeneous mixtures, and the evolution of its strength over time is not properly understood. However, the use of non-destructive methods, such as the ultrasound monitoring of structural changes, could be a quick and efficient way to predict material behavior (Beraldo [8], Teixeira [9], Beraldo [10]) The aim of this study was to evaluate cementitious matrices properties by partial replacement of Portland cement with SF or RHA, and to analyze their applications in nonbearing hollow blocks, tested by destructive and non-destructive methods.

\section{Materials and experimental program}

\subsection{Raw materials}

It was employed a residual rice husk ash (RHA), obtained by noncontrolled burning process in rice industry located in São Paulo State, Brazil. Silica fume (SF) was used as reference. These residues were used without any treatment.

Concrete hollow blocks were manufactured with ordinary Portland cement (CPV-ARI-40, according to Brazilian standard NBR 5733 [11]), natural sand, gravel and a plasticizer additive.

\subsection{Chemical and physical characterization of RHA and SF}

The chemical composition of residues was determined by X-ray fluorescence (XRF), and the loss on ignition (LOI) was determined by ASTM C-114 [12]. Mineralogical characterization of the ashes was carried out by $\mathrm{X}$-ray diffractions.

Granulometric size distributions of ashes were performed using a Malvern Mastersizer 2000 apparatus, which allows an analysis of particles by laser diffraction from 0.02 to $2000 \mu \mathrm{m}$, in liquid mode as dispersant, with $10 \%-15 \%$ of obscuration and ultrasonic agitation during $60 \mathrm{~s}$.

\subsection{Pozzolanic activity evaluation by electrical conductivity}

The development of the reaction of pozzolan/calcium hydroxide produces insoluble products, therefore the concentration of $\mathrm{CH}$ $\left[\mathrm{Ca}(\mathrm{OH})_{2}\right]$ in the solution decreases. The decrease of $\mathrm{Ca}^{2+}$ ions due to the increase phase of $\mathrm{CSH}$ (calcium silicate hydrate) produces a decrease in conductivity, which rate depends if the reactivity of the pozzolan is higher or lower (Villar-Cociña [13]). Several authors (Luxán [14], Tashiro [15], Payá [16]) applied the electrical conductivity test to evaluate the pozzolanic activity of a material. This test involves taking measurements of the electrical conductivity of a solution of calcium hydroxide and pozzolan, or those of RHA. Thus, a qualitative analysis is obtained by means of an electrical conductivity curve as a function of the time for RHA and for SF.

It was added $200 \mathrm{mg}$ of $\mathrm{Ca}(\mathrm{OH})_{2}$ in deionized water to obtain an unsaturated solution, at $60{ }^{\circ} \mathrm{C}$. After stabilization of the solution's conductivity, it was placed $5.25 \mathrm{~g}$ of ash into the solution, and electrical conductivity was obtained. Conductivity values were collected every $20 \mathrm{~s}$, and the test duration was $24 \mathrm{~h}$.

\subsection{Concrete hollow blocks manufacturing}

For the hollow blocks production, three difference mixtures were

Table 1 - Ratios used in the mixtures (by mass)

\begin{tabular}{|cccccccc} 
Mixtures & Portland cement & Waste & Sand & Gravel & Water/binder & Plasticizer additive \\
Control & 1 & - & - & - & 0.5 & - \\
Cement/RHA & 0.9 & 0.1 & 7.6 & 6.1 & 0.6 & 0.03 \\
Cement/SF & 0.9 & 0.1 & - & - & 0.7 & - \\
\hline
\end{tabular}




\section{Figure 1 - Directions of the measurements: height, length and width}

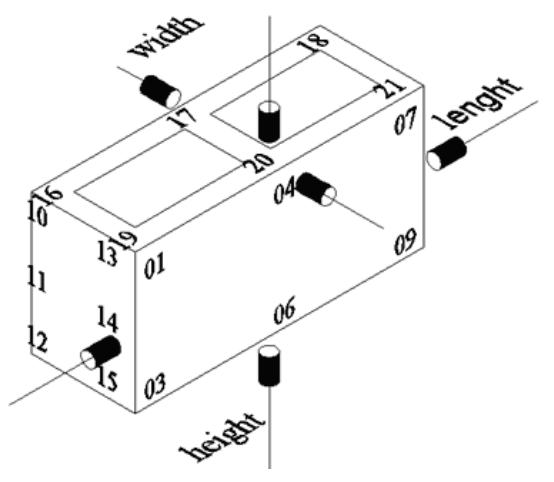

employed: a control ( $100 \%$ of Portland cement), blocks with RHA and blocks with SF. The percentage of replacement of Portland cement by ashes was $10 \%$. The ratios used in mixtures are presented in Table 1.

The materials were placed in a mixer, and after complete mixture's homogenization the mixture was pressed in a pneumatic machine Permac model MB0100. The pressure of the piston was $50 \mathrm{MPa}$. Hollow blocks were produced with dimensions of $390 \times 190 \times 140$ $\mathrm{mm}$, classified as M-15 block, according to Brazilian standard NBR 6136 [1]. The cure was performed in a laboratory environment with temperature range of $23 \pm 5{ }^{\circ} \mathrm{C}$.

\subsection{Ultrasonic pulse velocity (UPV)}

The same hollow blocks were tested by nondestructive test and then by the destructive one. UPV was recorded once a week during 28 days before the destructive test. An Ultrasonic Tester Steinkamp, model BP7, with exponential transducers with a resonance frequency of $45 \mathrm{kHz}$ was employed. Measurements were carried out in three directions of the blocks, height, length and width, as showed in Figure 1.

Statistical analysis was conducted by the Statgraphics Software, version Centurion XV.I. UPV's data were evaluated statistically aiming to obtain correlations with the compressive strength allowing applications for the control of material quality.

\subsection{Water albsorption test}

The blocks were subjected to the water absorption test at 28 days of age, according to Brazilian standard NBR 12118 [17]. Blocks were soaked in water at $23 \pm 5{ }^{\circ} \mathrm{C}$ during $24 \mathrm{~h}$, and then, they were weighed in saturated condition. Block's absorption was calculated according to equation 1 .

$$
w=\frac{m_{h}-m_{s}}{m_{s}} .100
$$

$\mathrm{w}(\%)=$ water absorption;

$\mathrm{m}_{\mathrm{h}}=$ block saturated mass $(\mathrm{kg})$;

$\mathrm{m}_{\mathrm{s}}=$ block dried mass $(\mathrm{kg})$.

\subsection{Compressive strength}

The test was conducted in a universal testing machine model DL30000, with device displacement of $2 \mathrm{~mm} \cdot \mathrm{min}^{-1}$. The results of the compressive strength (MPa) were obtained by dividing the maximum load $(\mathrm{N})$ by the area of section $\left(\mathrm{mm}^{2}\right)$, obtaining the average of repetitions, in accordance with standard. Data were analyzed by statistical software (Statgraphics). Average comparison was performed using the Tukey test at $5 \%$ of significance level.

\section{Results and discussion}

\subsection{Residues characterization}

Chemical composition and LOI of the residues are shown in Table 2. RHA shows high content of silica, thus corroborating the analysis presented by others researchers (Krishnaro [18], Bui [19]). Potassium content was low for both samples, which is a favorable aspect, as the presence of potassium may cause problems with alkali-aggregate reaction in the cement matrix. However, LOI for RHA was high. According to the Brazilian standard (NBR 12653 [20]), pozzolan maximum content must be $6 \%$ of LOI.

XRD patterns of SF and RHA are presented in Figures 2 and 3, respectively. As expected, crystalline phases were not identified for SF, and the amorphous material is evidenced. Peaks of cristobalite and quartz were observed at RHA diffractogram, showing the crystalline phases formation, probably as a consequence of non-controlled burning. The more crystalline ashes, the lower its reactivity (John [21]).

Table 3 and Figure 4 show the particle size distribution and particle size curve, respectively. It is observed that SF has the smallest particles size when compared to RHA; however, RHA has $90 \%$ of its particles below $80 \mu \mathrm{m}$, and it presents small average diameter. Materials with a high fineness may show high reactivity in contact with calcium hydroxide (NBR 12118 [17]). Moreover,

Table 2 - Chemical composition of RHA and SF

\begin{tabular}{cccccccccccccc}
\hline & $\mathrm{Na}_{2} \mathrm{O}$ & $\mathrm{MgO}$ & $\mathrm{Al}_{2} \mathrm{O}_{3}$ & $\mathrm{SiO}_{2}$ & $\mathrm{P}_{2} \mathrm{O}_{5}$ & $\mathrm{SO}_{3}$ & $\mathrm{Cl}$ & $\mathrm{K}_{2} \mathrm{O}$ & $\mathrm{CaO}$ & $\mathrm{MnO}$ & $\mathrm{Fe}_{2} \mathrm{O}_{3}$ & $\mathrm{LOI}$ \\
$\mathrm{SF}$ & 0.17 & 0.37 & 0.08 & 95.2 & 0.12 & 0.28 & 0.21 & 1.22 & 0.48 & 0.04 & 0.10 & 1.68 \\
$\mathrm{RHA}$ & 0.09 & 0.37 & 0.19 & 86.8 & 0.66 & 0.09 & 0.03 & 1.67 & 0.65 & 0.21 & 0.09 & 9.12 \\
\hline
\end{tabular}


Figure 2 - XRD pattern of SF

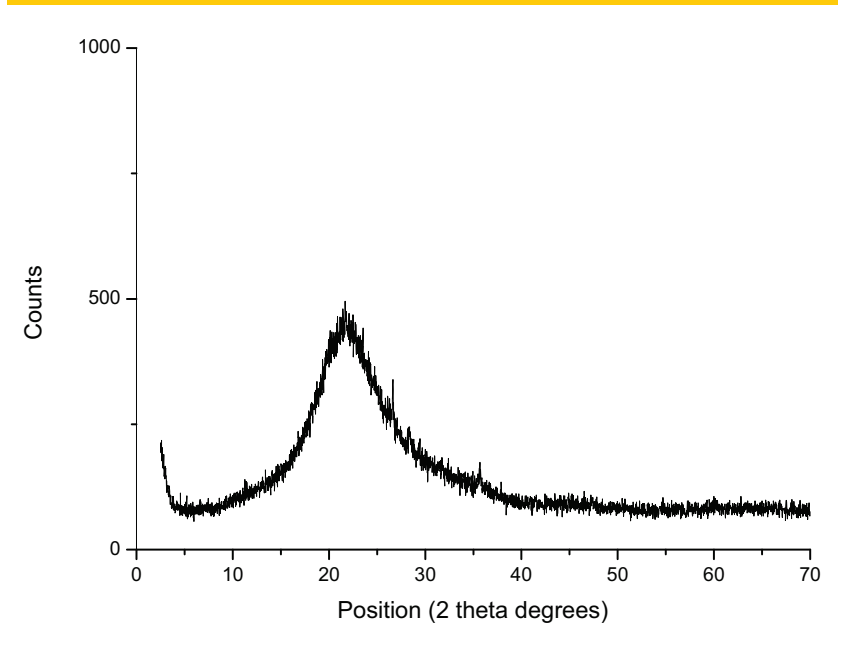

Figure 3 - XRD pattern of RHA

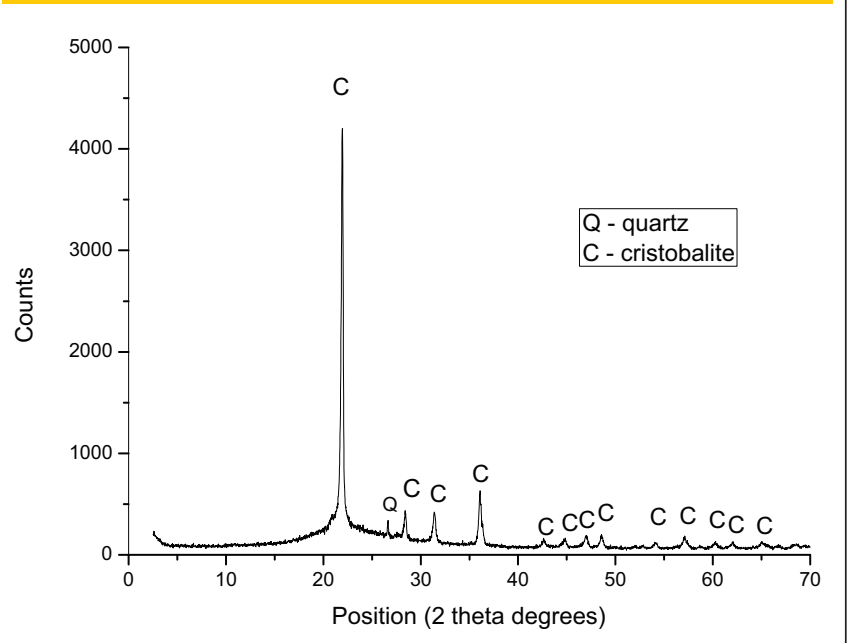

Table 3 - Particle size distribution

\begin{tabular}{|ccccc|}
\hline Samples & $\mathrm{D}_{10}(\mu \mathrm{m})$ & $\mathrm{D}_{50}(\mu \mathrm{m})$ & $\mathrm{D}_{90}(\mu \mathrm{m})$ & Average $(\mu \mathrm{m})$ \\
\hline RHA & 4.725 & 26.964 & 79.686 & 35.489 \\
SF & 3.945 & 18.983 & 42.466 & 21.315 \\
\hline
\end{tabular}

the fine material fills the voids and presents the effect of a "filler". With the combination of these two positive effects, a material might partially replace the cement with advantage, as it does not imply a large increase in water/binder ratio (Cordeiro [22]). In this work, it was observed a small increase of water/binder ratio in blocks produced with replacement (by SF or by RHA), due to the fineness of the materials.

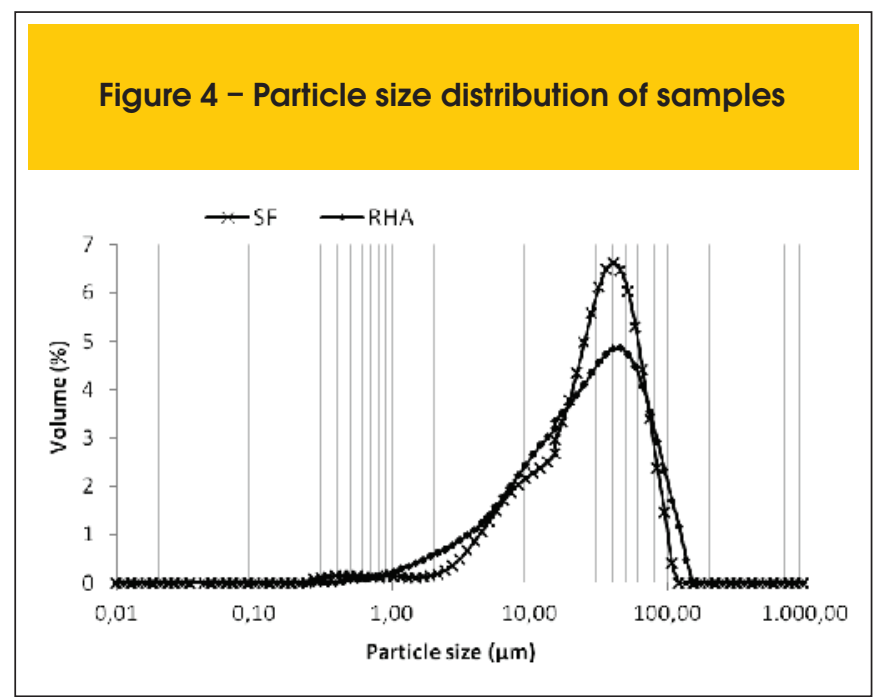

\subsection{Pozzolanic evaluation}

In order to evaluate the reactivity of RHA, the electrical conductivity of a solution of $\mathrm{CH}$ /ash was measured, which was also carried out for SF. The curves are shown in Figure 5.

It was observed that the $\mathrm{CH} / \mathrm{SF}$ solution is highly reactive, with large decreases in conductivity in the first hours. This behavior was already expected, as SF is well known as pozzolan. The

Figure 5 - Electrical conductivity curve of samples

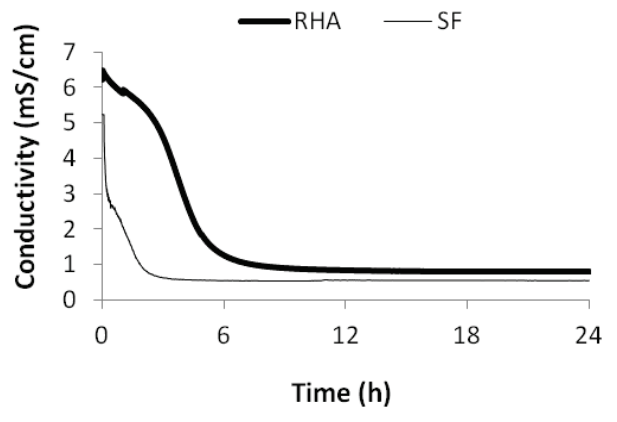




\section{Figure 6 - UPV of concrete hollow blocks at the transverse direction (width)}

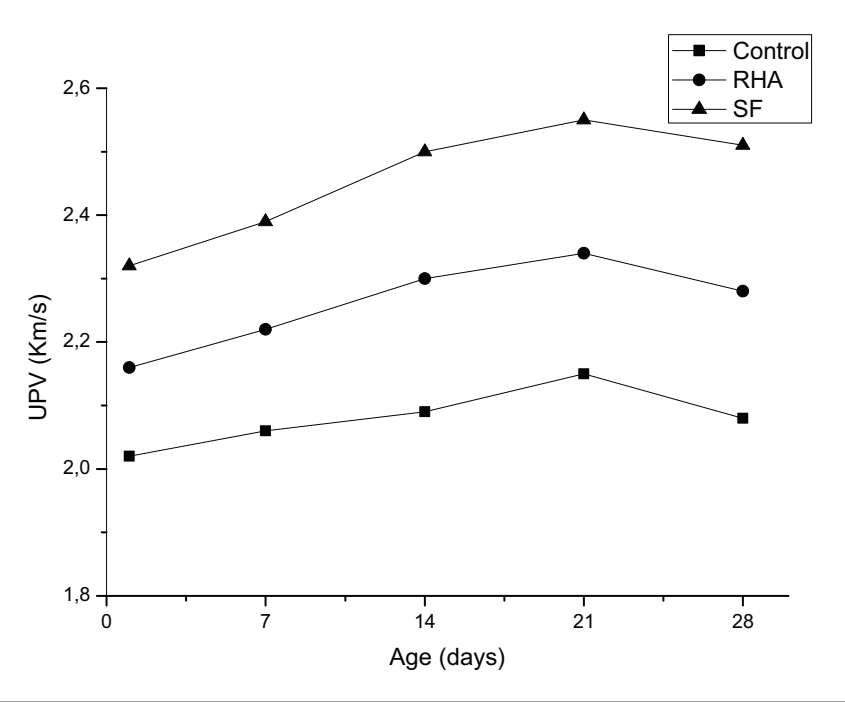

$\mathrm{CH} / \mathrm{RHA}$ curve shows the reactivity of this ash. It is observed that RHA reacts slower than SF; however, RHA presented low electrical conductivity, thus showing that it may indicate the formation of CSH products. After $12 \mathrm{~h}$, for both samples, it was observed the electrical conductivity stabilization, with values close to $0.5 \mathrm{mS} . \mathrm{cm}^{-1}$.

\subsection{Ultrasonic pulse velocity (UPV)}

Figures 6,7 and 8 show the ultrasonic pulse velocity (UPV) values across the concrete hollow blocks at three different directions, respectively width, length and height.

At the width direction (Figure 6), UPV across the hollow blocks with SF was higher than for other hollow blocks, which was expected, as SF is commercially known as a pozzolan, which presents high reactivity. It was observed that, as age increases, there was a small UPV variation across the blocks. There was a statistically significant difference among the UPV for all of the blocks.

At the length direction (Figure 7), it was observed a similar behavior with those from Figure 6 . However, control hollow blocks and RHA-based hollow blocks showed no statistical difference between them, but both were statistically different when compared to the SF-based hollow blocks, which showed the highest values of UPV.

\section{Figure 7 - UPV of concrete hollow blocks at the longitudinal direction (length)}

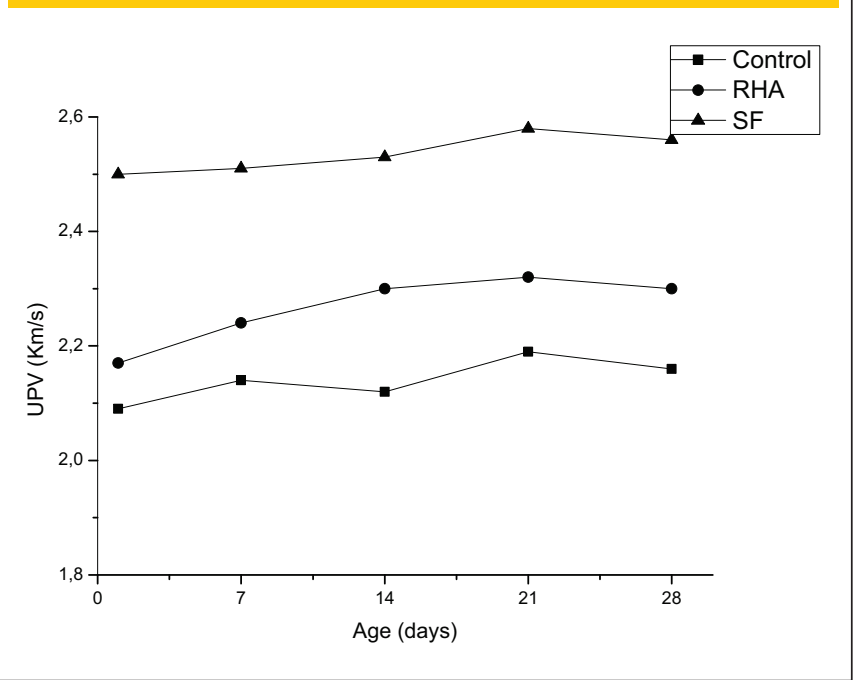

The same behavior was observed for the UPV at the height direction. UPV was higher across the SF-based hollow blocks.

RHA-based and SF-based hollow blocks present higher values of UPV when compared to the control ones due to the "filler" physical effect, with the filling of voids in concrete produced by the different particles size.

Statistical analysis comparing the UPV values at 7 days among the hollow blocks directions shows that there was a statistical significant difference. For length and width, there is no statistical difference; however, they showed statistical difference when compared with the height direction. The same behavior was observed when comparing UPV at 28 days. For the length and width directions, there is the effect of confinement of the wall mold, which does not happen to the height direction.

\subsection{Water absorption}

According to the Brazilian standard (NBR 12118 [17]), the maximum water absorption for concrete hollow blocks must be $15 \%$. It is observed in Table 4 that the hollow blocks manufactured with SF or RHA showed low water absorption, when compared to the control ones.

If pozzolanic reaction occurs, the products reaction formed are very effective in filling the capillary spaces, thus improving the mechanical strength and impermeability of the matrix (ASTM C55-11 [2]), as it was observed for the replacements tested.

Table 4 - Water absorption of hollow blocks

\begin{tabular}{|cccc|}
\hline Concrete hollow blocks & Water absorption $(\%)$ & Standard deviation & Coefficient of variation \\
\hline Control & 11.56 & - & - \\
Cement/RHA & 8.97 & 1,81 & 17,22 \\
Cement/SF & 8.67 & - & - \\
\hline
\end{tabular}


Figure 8 - UPV of concrete hollow blocks at the perpendicular direction (height)

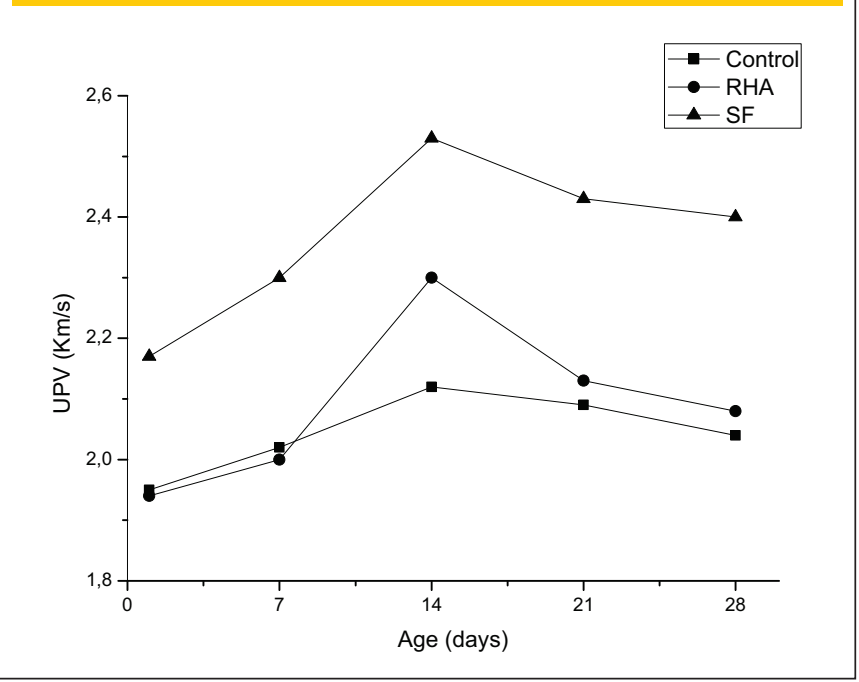

\subsection{Compressive strength of concrete hollow blocks}

As expected, the compressive strength of the SF-based hollow blocks was higher than the other ones (Figure 9). However, statistical analysis showed no statistically difference among the compressive strength of the hollow blocks from the three different mixtures employed (control, cement/SF, cement/RHA). Therefore, according to this test, it is possible to produce hollow blocks with partial replacement of Portland cement by RHA, without decreasing compressive strength.

Based on the results of physical and mechanical tests, it was observed that, in addition to the residues acting as pozzolans, they may also perform as fillers, thus contributing to lower water absorption and, therefore, increasing the durability of the hollow blocks.

\subsection{Correlation between UPV and compressive strength}

In order to obtain a correlation between UPV and compressive strength, a simple regression was performed. UPV data are related to height direction that was also considered for destructive test. The software used for regression analysis was Statgraphics. Despite a positive tendency of the compressive strength with respect to the UPV, the determination coefficient was only 0.38 , thus denoting a small dependence of the variables. The linear model presented by the software is presented by equation 2 .

$$
R_{c}=-1,1571+2,2177 \subset U P V
$$

$\mathrm{Rc}=$ compressive strength $(\mathrm{MPa})$;

UPV = ultrasonic pulse velocity $\left(\mathrm{km} \cdot \mathrm{s}^{-1}\right)$

\section{Conclusions}

The characterization of RHA showed high content of silica, low content of potassium and high fineness, thus denoting its reactivity. However, this ash presents high LOI content, and XRD showed a crystalline material with peaks of cristobalite and quartz. The pozzolanic assessment of RHA showed pozzolanic reactivity when evaluated by electrical conductivity in a $\mathrm{CH}$ /ash solution.

Non-destructive evaluation of the concrete hollow blocks showed that the highest values of UPV were obtained across the SF-based hollow blocks for three different directions. Statistical analysis showed that, for length and height directions, the UPV for these hollow blocks presents statistically significant difference when compared to the others ones. RHA-based hollow blocks and SFbased hollow blocks presented lower water absorption when compared to the control ones.

Despite SF-based hollow blocks showing the highest values of compressive strength, statistical analysis showed no statistically significant difference among the types of hollow blocks. Data correlation between UPV and compressive strength showed a small determination coefficient (0.38).

\section{References}

[01] Brazilian Technical Standard Association - Rio de Janeiro. NBR 6136 -Hollow concrete blocks for concrete masonry. Rio de Janeiro, Brazil, 2006.

[02] American Society for Testing and Materials - C55-11, Standard Specification for Concrete Building Brick. 2011.

[03] BS 6073/81 - Part 1 - Precast concrete masonry units - Specification for precast for concrete masonary units, 2011.

[04] Prassianakis, I.N.; Prassianakis, N.I. Ultrasonic testing of non-metallic materials: concrete and marble. Theoretical and Applied Fracture Mechanics. Amsterdam, 42 (2004) 191-198.

Figure 9 - Compressive strength of blocks Control $\square$ RHA $\square$ SF

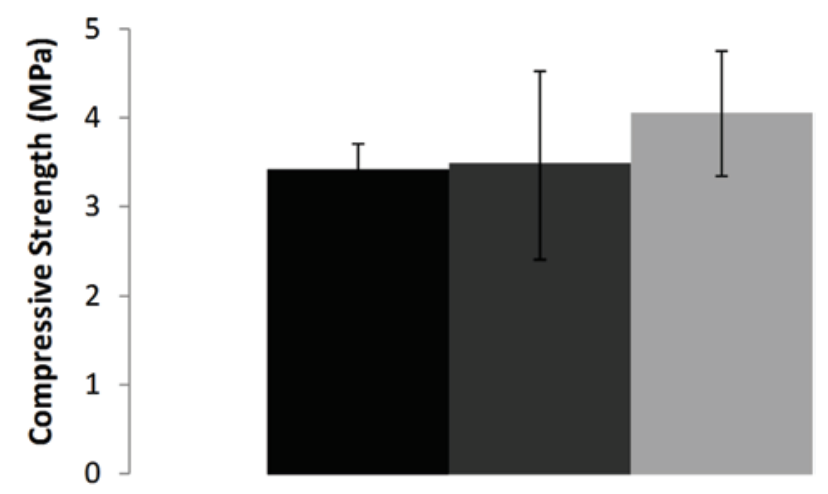


[05] Hamid, R.; Yosof, K.M.; Zain, M.F.M. A combined ultrasound method applied to high performance concrete with silica fume. Construction and Building Materials, vol. 24, 2010, p.94-98.

[06] Information on http://www.snic.org.br

[07] Mehta, P.K.; Monteiro, P.J.M. Concrete, structures, properties and materials. $1^{\text {st }}$.Ed., Pini, São Paulo, 1994, pp. 574.

[08] Beraldo, A.L. Ultrasonic speed wave: cure type influence on wood-cement composite compression strength. In: Proceedings of the NDTISS'99 International Symposium on Non Destructive Testing Contribution to the Infrastructure Safety Systems in the 21st Century, UFSM, Torres, RS, 1999 , pp. 86-90, 1999.

[09] Teixeira, D.E.; Molesmi, A. Assessing modulus of elasticity of wood-fiber cement (WFC) sheets using nondestructive evaluation (NDE). Bioresource Technology, 24 (2001) 193-198.

[10] Beraldo, A.L.; Martins, S.C.F. Destructive and non-destructive evaluation of bamboo chips - Portland cement composite. Journal of Bamboo and Rattan, 6 (2007) 61-70.

[11] Brazilian Technical Standard Association - Rio de Janeiro. NBR 5733 - High early strength Portland cement. Specification. Rio de Janeiro. 1991. 5p. (In Portuguese).

[12] American Society for Testing And Materials, Standard Test Method for Chemical Analysis of Hydraulic Cement: ASTM C114-03. 2003. Philadelphia.

[13] Villar-Cociña, E.; Valencia-Morales, E.; González-Rodríguez, R.; Hernández-Ruíz, $J$. Kinetics of the pozzolanic reaction between lime and sugar cane straw ash by electrical conductivity measurement: A kinetic-diffusive model. Cement Concrete Research, 33 (2003) 517-524.

[14] Luxán, M.P.; Madruga,F.; Saavedra, J. Rapid evaluation of pozzolanic activity of natural products by conductivity measurement. Cement and Concrete Research, 19 (1989) 63-68

[15] Tashiro, C.; Ikeda, K.; Inoue, Y. Evaluation of pozzolanic activity by electric resistance measurement method. Cement and Concrete Research, 24 (1994) 1133-1139.

[16] Payá, P.; Borrachero, M.V. ; Monzó, J. Peris-Mora, E.; Amahjour, F. Determination of amorphous silica in rice husk ash by a rapid analytical method. Cement and Concrete Research, 31 (2001) 227-231.

[17] Brazilian Technical Standard Association - Rio de Janeiro. NBR 12118 - Hollow concrete blocks for concrete masonry. Test method. Rio de Janeiro. 2007. 12p. (In Portuguese).

[18] Krishnarao, R.V.; Subrahmanyam, J.E.; Kumar, T.J. Studies on the formation of black particles in rice husk silica ash. Journal of the European Ceramic Society, 21 (2001) 99-104.

[19] Bui, D.D.; Hu, J.; Stroeven, P. Particle size effect on the strength of rice husk ash blended gap-graded Portland cement concrete. Cement \& Concrete Composites; 27(2005) 357-366.
[20] Brazilian Technical Standard Association - Rio de Janeiro. NBR 12653 - Pozzolans - Specification. Rio de Janeiro. 1992. 4p. (In Portuguese).

[21] John, V.M.; Cincotto, M.A.; Silva, M.G.; Ashes and Non Conventional Binders. In: Tecnology and Non Conventional Materials for Constructions. FREIRE, W. J. and BERALDO, A. L. (Coord.). Campinas, SP: UNICAMP Press, 2003. 145-190. (In Portuguese).

[22] Cordeiro, G.C. Ultrafine ashes from sugar-cane bagasse and rice husk as mineral additive for concrete. D.Sc. Thesis, COPPE, Universidade Federal do Rio de Janeiro - UFRJ, Rio de Janeiro, Brazil. 2006. (In Portuguese). 